Research Article

\title{
GC-MS, Molecular Docking and In vitro Studies of Methanolic Extract of Leaves of Jatropha gossypiifolia as Potent Anti-alzheimer's
}

\author{
S.Babyvanitha ${ }^{1}$, B.Jaykar ${ }^{2}$ \\ ${ }^{1}$ Assistant professor, Department of Pharmacology, Vinayaka Mission's College of Pharmacy, Vinayaka Missions Research Foundation \\ (deemed to be university), Kondappanaickenpatti, Yercaud main road, Salem 636008, Tamilnadu, India. \\ ${ }^{2}$ Registrar, Vinayaka Missions Research Foundation (deemed to be university) Salem, Tamilnadu, India. \\ *Corresponding author's E-mail: vanithabprakash@gmail.com
}

Received: 10-03-2021; Revised: 22-04-2021; Accepted: 29-04-2021; Published on: 15-05-2021.

\section{ABSTRACT}

The aim of this study is to explore anti-alzheimer's effect of phytocompounds identified from methanolic extract leaves of Jatropha gossypiifolia using GC-MS and Molecular docking studies. Acetylcholinesterase inhibitors improved cholinergic deficit in the brain which are beneficial in the treatment of Alzheimer's disease. In this research work we studied the AchE antagonistic effect of phytocompounds identified from Jatropha gossypiifolia using an in silico approach. This work reported the phytochemical analysis of the methanolic extract of the leaves of Jatropha gossypiifolia. Eleven compounds were revealed through GC-MS analysis and screened using GC-MS QP2010PLUS, Shimadzu, Japan. Interpretation on mass spectrum of GC-MS was done using the database of National Institute Standard and Technology (NIST). 1,1,5-Trimethyl-1, 2-dihydro naphthalene, Methyl 10,12-pentacosadiynoate, Dodecanoic acid, methyl ester, Methyl tetradecanoate, 3,7,11,15-Tetramethyl-2-hexadecen-ol, Cyclopropanepentanoic acid 2-undecyl, methyl ester-trans, N-hexadecanoic acid, 9,12,15- Octadecatrienoic acid, Heptadecanoic acid, 16-methyl methyl ester, 7,8 Epoxylanostan 11ol, 3-acetoxy, Cis,Cis, Cis - 7,10,13 - Hexadecatrienal compounds identified from methanolic leaf extract of Jatropha gossypiifolia using GC-MS analysis. Molecular docking of Jatropha gossypiifolia on human AchE protein was determined by using AutoDock Vina software and compared with Donepezil a known reversible acetylcholinesterase inhibitor. The interactions of Human Acetylcholinesterase-ligand conformations, including hydrogen bonds and various other bonds were analyzed using BIOVIA Discovery Studio 2016. Cis, Cis, Cis - 7,10,13-Hexadecatrienal existing phytochemicals from the leaves of Jatropha gossypiifolia had the highest fitness score of $-7.6 \mathrm{kcal} / \mathrm{mol}$ comparable with donepezil having $-9.2 \mathrm{kcal} / \mathrm{mol}$ and hence could be a potent antialzheimer's drugs.

Keywords: Jatropha gossypiifolia, GC-MS, Docking studies, Acetylcholinesterase.

QUICK RESPONSE CODE $\rightarrow$

DOI:

10.47583/ijpsrr.2021.v68i01.034

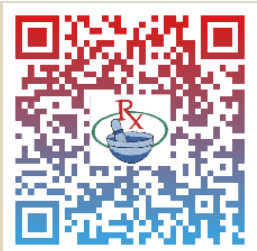

DOI link: $\underline{\text { http://dx.doi.org/10.47583/ijpsrr.2021.v68i01.034 }}$

\section{INTRODUCTION}

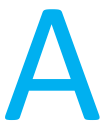

Izheimer disease is characterized by the accumulation of $A \beta$ plaques around the neurons extracellularly and formation of neurofibrillary tangles by hyperphosphorylation of Tau proteins intracellularly that results decrease in the level of Ach neurotransmitter. ${ }^{1}$ In brain cholinergic neurons synthesise acetylcholine a neurotransmitter involved in the signal transmission and delivery of messages in the brain. ${ }^{2,3}$ It plays an important role in learning and memory. ${ }^{4,5}$ Deposition of plaques and neurofibrillary tangle in the brain which leads to degradation of the cholinergic neurons in the hippocampal and cortical part of the brain and decrease in the level of acetylcholine. ${ }^{6-10}$ Decrease acetylcholine level is responsible for unregulated signal transmission of the cholinergic pathway which is accompanied by AD.

Hence the AchE inhibitors are beneficial in the treatment of Alzheimer's disease. Currently two pharmacotherapy's are approved by Food and Drug Administration (FDA) i.e. Acetyl cholinesterase inhibitor like Tacrine, Donepezil, Rivastigmine, Galantamine and N-methyl D-aspartate, glutamate antagonist (NMDA) - Memantine.

Jatropha gossypiiflia, commonly known as bellyache bush. It grows up to $2.5-4 \mathrm{~m}$ (8.2-13.1 ft) height. The three lobed leaves are purple and sticky when young and become bright green with age. The small red flowers with yellow centres appear in clusters. These are followed by cherrysized seed pods that are poisonous. It possess different biological activities like Analgesic activity, Neuropharmacological activity, Anxiolytic activity, Antidiarrhoeal activity, Anti-cancer activity, Hepatoprotective activity, Hypotensive and Vasorelaxant effect, Antimicrobial activity, Haemostatic agent, Anti-diabetic activity, Anti-inflammatory activity.

\section{MATERIALS AND METHODS}

\section{SELECTION OF THE PLANT}

Drug discovery from medicinal plants has evolved to include numerous fields of inquiry and various methods of analysis. The process typically begins with a botanist, ethno botanist, ethno pharmacologist, or plant ecologist who identifies the plant of interest. Collection may involve 
species with known biological activity for which active compounds have not been isolated or may involve taxa collected randomly for a large screening program. On the basis of intensive literature survey; Jatropha gossypiifolia, leaveswere selected for present study.

\section{Collection and Authentication of Plant Material:}

The plant Jatropha gossypiifolia leaves had been collected from ABS botanical garden, Salem, Tamil Nadu, India. The plant was identified and authenticated by the botanist Mr.A.Balasubramanian (consultant - central siddha research) Executive Director ABS botanical, Salem, Tamil Nadu.

\section{Extraction of Plant Material}

The fresh leaves of Jatropha gossypiifolia are collected and dried under shade, sliced into small pieces and ground into powder with mechanical grinder and the powder was sieved by Sieve no.30 and preserved in a container.

\section{Solvents for Extraction}

Petroleum ether $\left(60-80^{\circ} \mathrm{C}\right)$

Chloroform

Methanol

\section{Extraction procedure}

The dried powder of leaves of Jatropha gossypiifolia was defatted with petroleum ether in Soxhlet apparatus by hot percolation. The defatted powder material (marc) thus obtained was further extracted with Chloroform and methanol. The solvent was removed by distillation under reduced pressure and evaporation. The resulting semisolid mass was vaccum dried by using rotary flash evaporator.

\section{Preliminary Phytochemical Studies ${ }^{11-14}$}

The extract was subjected to preliminary phytochemical investigations to identify various phytoconstituents present in the leaves of Jatropha gossypiifolia.

\section{Identification of Phytochemical Constituents using Gas Chromatography. ${ }^{15}$}

GC-MS analysis was carried out by GC-MS QP2010PLUS, Shimadzu, Japan coupled with mass spectrometry as detector. The temperature was adjusted to $-30^{\circ} \mathrm{C}$ to $280 / 300^{\circ} \mathrm{C}$, the HP-5MS column with dimensions $30 \mathrm{~m} \mathrm{X}$ $0.32 \mathrm{~mm} \times 0.25 \mu \mathrm{m}$ was used for analysis. The oven temperature was adjusted to $35^{\circ} \mathrm{C}$ and hold time $5 \mathrm{~min}$ and, ramp $10^{\circ} \mathrm{C} / \mathrm{min}$ up to $220^{\circ} \mathrm{C}$. Column flow is $1.2 \mathrm{ml}$. The inlet temperature was kept at $250^{\circ} \mathrm{C}$ and the source temperature of $230^{\circ} \mathrm{C}$ and $\mathrm{MS}$ Quard temperature of $150^{\circ} \mathrm{C}$.

\section{Molecular docking studies. ${ }^{16}$}

Human Acetyl cholinesterase binding mode and interaction with individual Phytoconstituent was performed using AutoDock Vina software. Possible conformations and orientations for the ligand at the binding site were obtained by Molecular docking. The PyRx software used to load the protein, creating a PDBQT file which contains a protein structure with hydrogens in all polar residues. All ligand bonds were set to be rotatable. The protein-fixed ligand-flexible docking calculations were done using the Lamarckian Genetic Algorithm (LGA) method. The docking site on protein target was defined by establishing a grid box with the dimensions of $X: 38.0729$ Y: $33.3208 \mathrm{Z}$ : $25.0000 \AA$, with a grid spacing of $0.375 \AA$, centered on X: 20.2892 Y: 10.3219 Z: $32.3218 \AA$. The lowest docked energy was chosen as best conformation, after the docking search was completed. Eight runs with AutoDock Vina were performed in all cases per each ligand structure, and for each run the best pose was saved. The best poses average affinity was taken as the final affinity value. The interactions of Human Acetylcholinesterase-ligand conformations, including hydrogen bonds and various other bonds were analyzed using BIOVIA Discovery Studio 2016.

\section{Preparation of protein}

The water molecules, cofactors, and other ligands were removed from Crystal Structure of Recombinant Human Acetylcholinesterase in complex with Donepezil (PDB ID $4 \mathrm{EY7}$ ) through Molegro molecular viewer. Then they were used for molecular docking studies

\section{Preparation of ligands}

The crystal 3D structures of the active compounds were retrieved from PubChem database. Energy minimization was done using Open babel version 2.4.1

\section{In vitro study ( $A \beta_{1-42}$ intoxicated $\mathrm{SH}-\mathrm{SY} 5 Y$ cell lines model)} Cell viability assessment - MTT assay ${ }^{17}$

SH-SY5Y human neuroblastoma cell lines were obtained from National Centre for Cell Science (NCCS), Pune, India and maintained in Minimum Essential Medium (MEM) as per the standard protocol supplemented with $10 \%$ fetal bovine serum (FBS), streptomycin $(250 \mu \mathrm{g} / \mathrm{ml})$, gentamycin $(400 \mu \mathrm{g} / \mathrm{ml})$, amphotericin $(3 \mu \mathrm{g} / \mathrm{ml})$, and penicillin (250units $/ \mathrm{ml}$ ) in a carbon dioxide incubator at $5 \% \mathrm{CO}_{2}$. The viability of neuron in terms of mitochondrial metabolic function was evaluated by MTT [(3-[4, 5-dimethylthiazol-2yl]-2, 5 diphenyl tetrazolium bromide)] assay based on the principle involving reduction of MTT to formazan. To assess the protective effect, the SH-SY5Y cells were incubated with $A \beta_{1-42}(10 \mu \mathrm{M})$ for $24 \mathrm{hrs}$ and then posttreatment were made with methanolic extract of leaves of Jatropha gossypiifolia using its $\mathrm{IC}_{50}$ value. Then SH-SY5Y cells were washed with phosphate-buffered saline (PBS) and incubated with MTT $(5 \mathrm{mg} / \mathrm{ml})$ in PBS for 3 hours at $37^{\circ} \mathrm{C}$ in $5 \% \mathrm{CO}$. After further washing, the formazan crystals were dissolved with isopropanol and the absorbance was measured at $570 \mathrm{~nm}$. The percentage of viability of SH-SY5Y cells were calculated by the standard formula. 


\section{$A B_{1-42}$ intoxication and extract treatment}

The SH-SY5Y cell lines were maintained in Minimum Essential Medium (MEM) as per the standard protocol. 5000-10000 cells/well were seeded in 96 well plates and the viability was tested using trypan blue dye and $95 \%$ of viability was confirmed with help of haemocytometer. The cells were then incubated with $A \beta_{1-42}(10 \mu \mathrm{M})$ for $24 \mathrm{hrs}$. Then posttreatment with methanolic extract of leaves of Jatropha gossypiifolia using $\mathrm{IC}_{50}$ values were made. After 24 hours of treatment with respective extracts the following evaluations were performed.

\section{Cell morphological observation}

The phase contrast microscopy (Motic) was used to observe morphological changes in the SH-SY5Y cell lines.

\section{Preparation of cell lysates}

After study period, the medium was aspirated and cells were washed with the ice cold phosphate buffer saline, scraped, and were centrifuged at $5000 \mathrm{rpm}$ for $5 \mathrm{~min}$ at 4 ${ }^{\circ} \mathrm{C}$. The cell pellets were resuspended in $2000 \mu \mathrm{l}$ of lysis buffer (10mM Tris - $\mathrm{HCl}$, pH 7.5, 50mM NaCl, 5mM EDTA, $1 \%$ Triton X-100, 100 $\mu \mathrm{M}$ Na3VO4, 50mM NaF, $1 \mathrm{mM}$ PMSF, $10 \mu \mathrm{g} / \mathrm{ml}$ aprotinin $10 \mu \mathrm{g} / \mathrm{ml}$ and leupeptin,) and incubated on ice for $30 \mathrm{~min}$. The cell lysates were obtained by centrifugation at $12000 \mathrm{rpm}$ for $20 \mathrm{~min}$ at $4{ }^{\circ} \mathrm{C}$. Then obtained cell lysates were stored at $-20^{\circ} \mathrm{C}$ until use.

\section{Lipid peroxidation (LPO) assay ${ }^{18}$}

Lipid peroxidation was evaluated in cell lysates by measuring the malondiaaldehyde content according to the TBA test described by ohkawa et al., with slight modification. $0.8 \mathrm{ml}$ saline, $0.5 \mathrm{ml}$ of BHT and $3.5 \mathrm{ml}$ TBA reagent $(0.8 \%)$ were added to $0.2 \mathrm{ml}$ of the cell lysate, and incubated at $60^{\circ} \mathrm{C}$. After cooling, the solution was centrifuged at $2000 \mathrm{rpm}$ for 10 minutes. The absorbance of the supernatant was measured at $532 \mathrm{~nm}$ using spectrophotometer against the blank.

\section{Nitric Oxide (NO) assay ${ }^{19}$}

This assay was done by taking $0.2 \mathrm{ml}$ of medium with 1.8 $\mathrm{ml}$ of saline and $0.4 \mathrm{ml}$ of $35 \%$ sulphosalicylic acid (SSA) for protein precipitation. And the precipitate was removed by centrifugation at $4000 \mathrm{rpm}$ for $10 \mathrm{~min}$. To $1 \mathrm{ml}$ of aliquot of supernatant, $2 \mathrm{ml}$ Griess reagent (1g of sulphanilamide dissolved in small volume of water, $2 \mathrm{ml}$ of orthophosphoric acid and $100 \mathrm{mg}$ of naphthyl ethyldiamine were added and the final volume was made upto $100 \mathrm{ml}$ with distilled water) was added and the mixture was allowed to stand for 20 min under dark conditions. The colour intensity of the chromogen was read at $540 \mathrm{~nm}$. Standard calibration curve was plotted using sodium nitrite in the concentration range 2001000ng.

\section{Reduced glutathione (GSH) ${ }^{20}$}

GSH content was determined by following the method of Jollow et al. (1974). To $0.25 \mathrm{ml}$ of cell lysate an equal volume of ice-cold 5\% TCA was added. The precipitate was removed by centrifugation at $4000 \mathrm{rpm}$ for $10 \mathrm{mins}$. To $1 \mathrm{ml}$ aliquot of supernatant, $0.25 \mathrm{ml}$ of $0.2 \mathrm{M}$ phosphate buffer $(\mathrm{pH} 8.0)$ and $0.5 \mathrm{ml}$ of DTNB $(0.6 \mathrm{mM}$ in $0.2 \mathrm{M}$ phosphate buffer, $\mathrm{pH}$ 8.0) were added and mixed well. The absorbance was measured at $412 \mathrm{~nm}$ using spectrophotometer (UV, Shimadzu, Japan).

\section{Superoxide dismutase (SOD) ${ }^{21}$}

To $0.05 \mathrm{ml}$ of cell lysate, $0.3 \mathrm{ml}$ of sodium pyrophosphate buffer $(0.025 \mathrm{M}, \mathrm{pH}$ 8.3) was added. To this mixture, $0.025 \mathrm{ml}$ and $0.075 \mathrm{ml}$ of PMS $(186 \mu \mathrm{M})$ and NBT $(300 \mu \mathrm{M}$ in buffer, $\mathrm{pH}$ 8.3) were added. The reaction was initiated by the instillation of $0.075 \mathrm{ml}$ of $\mathrm{NADH}$. The mixture was then incubated at temperature of $30^{\circ} \mathrm{C}$ for a period of 90 seconds. To this $0.25 \mathrm{ml}$ of glacial acetic acid was added inorder to arrest the ongoing reaction. $\mathrm{N}$-butanol $(2 \mathrm{ml})$ was shaken vigorously along with the reaction mixture and the mixture was centrifuged at $4000 \mathrm{rpm}$ for $1 \mathrm{~min}$. The colorimetric analysis with $\mathrm{n}$-butanol $(1.5 \mathrm{ml})$ serving as blank was carried out at $560 \mathrm{~nm}$ using spectrophotometer.

\section{Catalase (CAT) $)^{22}$}

A small quantity of cell lysate $(100 \mu \mathrm{l})$ or sucrose $(0.32 \mathrm{M})$ was subjected to incubation with potassium phosphate buffer $(2.25 \mathrm{ml}) 65 \mathrm{mM}$ at $\mathrm{pH} 7.8$ for $30 \mathrm{~min}$ at $25^{\circ} \mathrm{C}$. The reaction was initiated by the addition of hydrogen peroxide $(7.5 \mathrm{mM} ; 650 \mu \mathrm{l})$. The absorbance change was recorded for a period of 2 to $3 \mathrm{~min}$ at 240 $\mathrm{nm}$ (UV, Shimadzu, Japan).

\section{Protein estimation ${ }^{23}$}

Protein content in the cell lysate was estimated as described by Lowry et al., 1951 to quantify the above parameters per mg protein.

\section{Measurement of IL-1 $\beta$ \& TNF- $\alpha$ (Pro-inflammatory cytokines) by ELISA ${ }^{24}$}

The levels of IL-1 $\beta$ and TNF- $\alpha$ were assessed in cell lysates by using respective ELISA kits (Invitrogen, R\&D systems \& Alpha diagnostics, USA) as per the manufacturer's protocol. Briefly, $150 \mu$ distilled water was added to the standard and blank wells for standard calibration and 100 $\mu \mathrm{l}$ distilled water and $50 \mu \mathrm{l}$ of each supernatant were added in duplicate into the wells. After incubation for 3 hours at room temperature, the wells were emptied and washed three times with $150 \mu$ l of wash buffer. TMB substrate $(100 \mu \mathrm{l})$ was added to each well and incubated for $15 \mathrm{~min}$ at room temperature, followed by addition of $100 \mu \mathrm{l}$ stop - solution to all wells including blank wells. The absorbance was determined at $410 \mathrm{~nm}$ using above mentioned ELISA reader.

\section{RESULTS}

The preliminary phytochemical studies of methanolic extract of leaves of Jatropha gossypiifolia showed the presence of phenolic compounds \& flavonoids, Carbohydrates \& glycosides, Protein \& aminoacids, Alkaloids, Phytosterol, Saponins. 
Table 1: Preliminary phytochemical studies of methanolic extract of leaves of Jatropha gossypiifolia

\begin{tabular}{|c|c|c|c|c|}
\hline $\begin{array}{l}\text { Phytochemical } \\
\text { constituents }\end{array}$ & Test & $\begin{array}{c}\text { Petroleum ether } \\
\text { extract }\end{array}$ & Chloroform extract & Methanol extract \\
\hline \multirow[t]{4}{*}{ Carbohydrates } & Molisch's test & - & + & + \\
\hline & Fehling's test & - & + & + \\
\hline & Barfoed's test & - & + & + \\
\hline & Borntrager's test & - & + & + \\
\hline Glycosides & Molisch's test & - & - & + \\
\hline \multirow[t]{4}{*}{ Protein \& aminoacids } & Biuret's test & + & - & - \\
\hline & Ninhydrin test & + & - & - \\
\hline & Xanthoprotein test & + & - & - \\
\hline & Millon's test & + & - & - \\
\hline \multirow[t]{3}{*}{ Alkaloids } & Mayer's test & - & + & ++ \\
\hline & Hager's test & - & + & ++ \\
\hline & Wagner' test & - & + & ++ \\
\hline Phytosterol & $\begin{array}{l}\text { Libermann's sterols } \\
\text { test }\end{array}$ & + & + & ++ \\
\hline Saponins & Salwoski's test & + & - & ++ \\
\hline \multirow{3}{*}{$\begin{array}{l}\text { Phenolic compound } \\
\text { and Tannins }\end{array}$} & Extract $+\mathrm{FeCl}_{3}$ & - & ++ & ++ \\
\hline & Gelatin test & - & ++ & ++ \\
\hline & $\mathrm{FeCl}_{3}$ & - & & \\
\hline \multirow[t]{3}{*}{ Flavonoids } & $\mathrm{AqNaOH}$ & - & ++ & +++ \\
\hline & Shinoda test & - & ++ & +++ \\
\hline & Conc. $\mathrm{H}_{2} \mathrm{SO}_{4}$ & - & ++ & +++ \\
\hline
\end{tabular}

\section{GC-MS analysis of MEJG}

The crude methanolic extract of leaves of Jatropha gossypiifolia was injected for screening of total active compounds by using GC-MS analyser. Eleven compounds were identified from the methanolic leaves extract Jatropha gossypiifolia. The retention for bioactive compounds of leaves extract ranged from 8.468 to 43.117 . The compound identified from the methanolic extract of Jatropha gossypiifolia using full mass spectrometry showed the presence of 1,1,5-Trimethyl-1,2-dihydronaphthalene, Methyl 10,12-pentacosadiynoate, Dodecanoic acid, methyl ester, Methyl tetradecanoate, 3,7,11,15-Tetramethyl-2hexadecen-1-ol, Cyclopropanepentanoic acid, 2-undecyl-, methyl ester, trans-, n-hexadecanoic acid, 9,12,15Octadecatrienoic acid (Z,Z,Z)-, Heptadecanoic acid, 16methyl-methyl ester-, 7,8-Epoxylanostan-11-ol, 3-acetoxy, Cis, Cis, Cis- 7,10,13 Hexadecatrienal. Mass spectrum of a few compounds like Heptadecanoic acid, 16-methyl-methyl ester-, and Cis, Cis, Cis- 7, 10, 13 Hexadecatrienal were discussed in the present study.

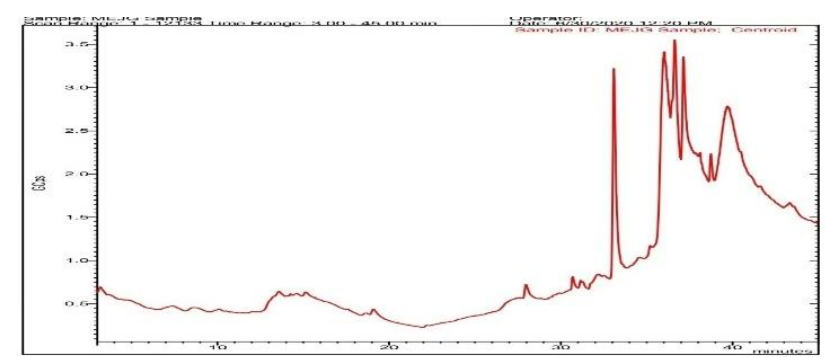

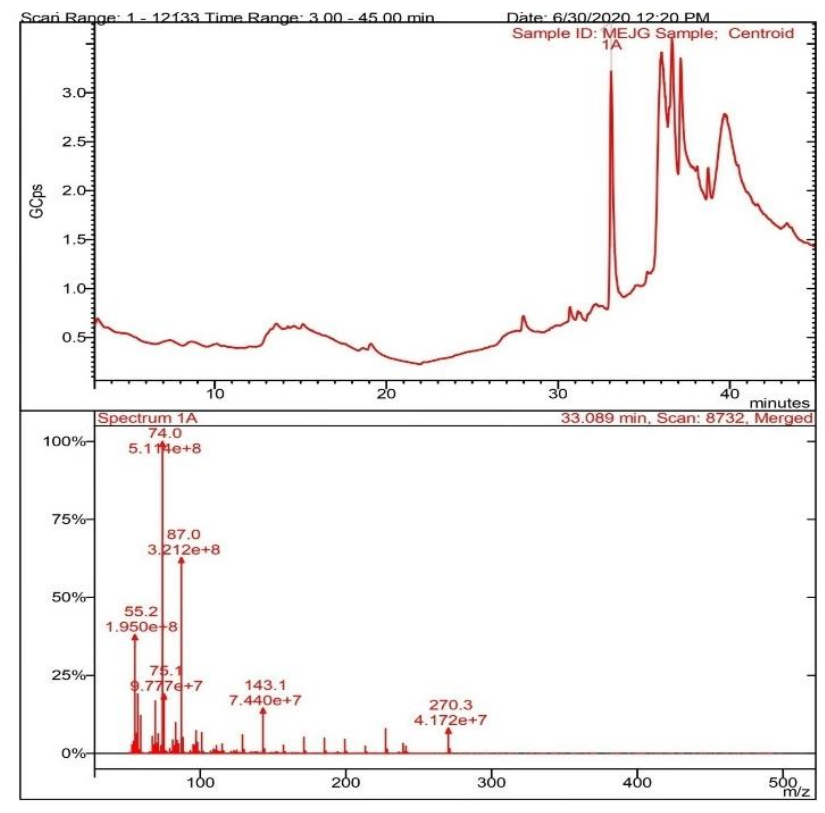

Figure 1: Mass Spectrum of methanolic extract of leaves of Jatropha gossypiifolia

\section{Molecular docking Studies \\ Structure based drug design}

From PDB acetylcholinesterase enzyme (PDB ID 4EY7) was downloaded, it was prepared by removing chain B. Water molecule present in both the chain are removed. Energy minimization was done. Molecules drawn using 
chemsketch were converted to mol format and ligprep was created.

\section{Screenshot showing protein - ligand interactions}

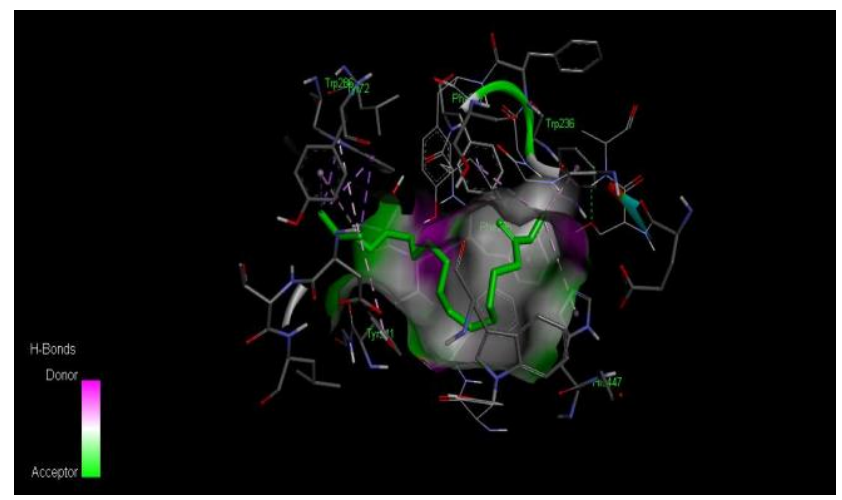

Figure 2: Steroview of compound BV1 on enzyme 4EY7

Compound BV1 shows their pi-sigma interactions over the enzyme TRP A: 286, pi-alkyl interactions in PHE A: 297, 295, TRIP A: 236, HIS A 447, TYR A: 341, 72, and has a vanderwaals interactions in AGR A: 296, VAL A: 294, TYR A: 124, GLY A: 121, 122. PHE A: 338, ALA A: 204, SER A: 203, TYR A: 337.

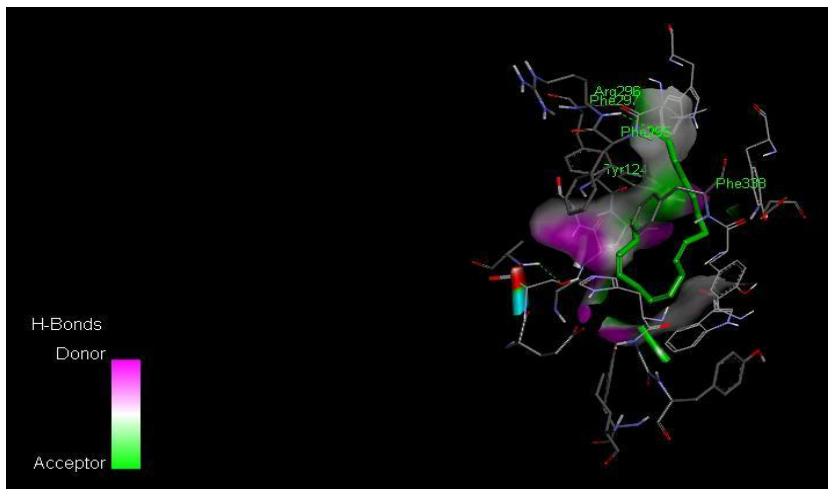

Figure 3: Stereoview of Compound BV2 on enzyme 4EY7

Docking analysis of compound BV2 shows their covalent hydrogen bond interactions over their enzyme ARG B: 296, PHE B: 295 and pi- alkyl interactions with PHE B: 338, 297, TYR B: 124 and has a vanderwaals interactions in VAL B: 294, TRP B 286, 86, GLY B: 448, SER B: 203, GLY B: 121, 122, TYR B: 341,337 , HIS B: 447.

\section{Donepezil}

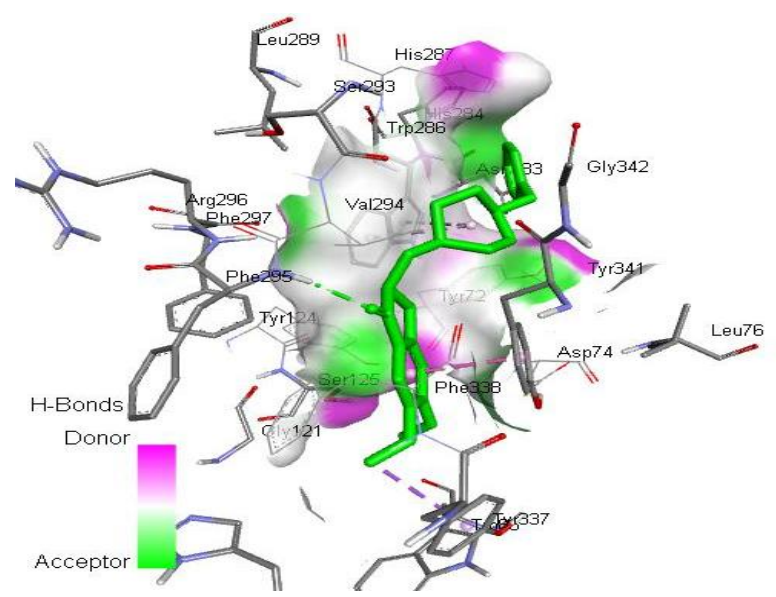

Binding affinity of the compounds with Donepezil (PDB ID 4EY7)

Table 2: Binding affinity of the compounds with Donepezil (PDB ID 4EY7)

\begin{tabular}{|c|c|c|c|}
\hline Ligand & Target Protein & $\begin{array}{l}\text { Binding } \\
\text { Affinity }\end{array}$ & RMSD \\
\hline $\begin{array}{l}\text { Heptadecanoic,16- } \\
\text { Methyl acid } \\
\text { methyl ester (BV1) }\end{array}$ & \multirow{3}{*}{$\begin{array}{l}\text { Recombinant } \\
\text { Human } \\
\text { Acetylcholinesterase } \\
\text { in complex with } \\
\text { Donepezil } \\
\text { (PDB ID 4EY7) }\end{array}$} & -7.0 & 3.232 \\
\hline $\begin{array}{l}\text { Cis, Cis, Cis } \\
7,10,13- \\
\text { Hexadecatrienal } \\
\text { (BV2) }\end{array}$ & & -7.6 & 0 \\
\hline $\begin{array}{l}\text { Standard } \\
\text { (Donepezil) }\end{array}$ & & -9.2 & 0 \\
\hline
\end{tabular}

In Vitro cytotoxicity MTT assay of methanolic extract of leaves of Jatropha gossypiifolia in SH-SY5Y cell lines

Table 3: MTT assay results

\begin{tabular}{|c|l|c|}
\hline SI No. Sample Description & $\begin{array}{c}\text { SHSY5Y } \\
\text { IC }_{50} \mathbf{\mu g} / \mathbf{m I}\end{array}$ \\
\hline $\mathbf{1}$ & $\begin{array}{l}\text { Methanolic extract of leaves of } \\
\text { Jatropha Gossypiifolia }\end{array}$ & $\mathbf{5 5 . 3 5 7 8 9}$ \\
\hline
\end{tabular}

Cell viability assessment - MTT assay [in presence of amyloid-beta 1-42 $\left.\left(A \beta_{1-42}\right)\right]$

Table 4: Cell viability assessment

\begin{tabular}{|l|l|l|}
\hline S. No & Groups & \% viability of cells \\
\hline $\mathbf{1}$ & Control & $99.87 \pm 0.143$ \\
\hline $\mathbf{2}$ & Aß1-42 (10 $\mu \mathrm{M})$ & $11.22 \pm 0.473^{* * *}$ \\
\hline $\mathbf{3}$ & met-L-JG & $77.96 \pm 1.321^{\# \# \#}$ \\
\hline
\end{tabular}

Effect of methanolic extract of leaves of Jatropha Gossypiifolia (met-L-JG) on cell viability level in A $\beta 1-42$ intoxicated SH-SY5Y cell lines. Statistical significance was determined by one way ANOVA followed by Tukey's multiple comparison tests using Graph pad prism Version 6.0. Values are represented as Mean \pm SEM, Superscript *** denotes $p<0.001$ vs control, \#\#\# denotes $p<0.001$; vs $A \beta 1$ 42 groups respectively, ( $A \beta$ : Amyloid beta). 
Anti-oxidant evaluation - Spectroscopy methods.

Table 5: Effect of methanolic extract of leaves of Jatropha Gossypiifolia (met-L-JG) on LPO, NO, GSH, SOD, CAT level in Aß142 intoxicated SH-SY5Y cell lines.

\begin{tabular}{|l|l|l|l|l|l|l|}
\hline S.NO & Groups & $\begin{array}{l}\text { LPO } \\
\text { (nmoles/ml) }\end{array}$ & NO (nmoles/ml) & $\begin{array}{l}\text { GSH }(\mu M / m g \\
\text { protein) }\end{array}$ & $\begin{array}{l}\text { SOD } \\
\text { protein) }\end{array}$ & $\begin{array}{l}\text { (U/mg } \\
\text { pAT(U/mg } \\
\text { protein) }\end{array}$ \\
\hline 1 & Control & $12.93 \pm 1.74$ & $24.20 \pm 2.10$ & $85.55 \pm 4.33$ & $25.17 \pm 2.28$ & $0.907 \pm 0.090$ \\
\hline 2 & A $1-42(10 \mu M)$ & $95.30 \pm 3.38^{* * *}$ & $147.63 \pm 2.39^{* * *}$ & $11.23 \pm 1.44^{* * *}$ & $3.54 \pm 0.87^{* * *}$ & $0.172 \pm 0.035^{* * *}$ \\
\hline 3 & Met-L-JG & $53.62 \pm 2.33^{\# \# \#}$ & $88.81 \pm 4.25^{\# \# \#}$ & $71.28 \pm 4.87^{\# \# \#}$ & $17.58 \pm 0.84^{\# \# \#}$ & $0.723 \pm 0.017^{\# \# \#}$ \\
\hline
\end{tabular}

Statistical significance was determined by one way ANOVA followed by Tukey's multiple comparison tests using Graph pad prism Version 6.0 . Values are represented as Mean \pm SEM, Superscript *** denotes $p<0.001$ vs control, \#\#\# denotes $p<0.001 ;$ vs $A \beta 1-42$ groups respectively, (A $\beta$ : Amyloid beta).

\section{Anti-Inflammatory assessments- ELISA}

Table 6: Effect of methanolic extract of leaves of Jatropha Gossypiifolia (met-L-JG) on IL-1 $\beta$ and TNF- $\alpha$ level in $A \beta_{1-42}$ intoxicated SH-SY5Y cell lines.

\begin{tabular}{|c|c|c|c|}
\hline S.NO & Groups & IL-1 $\beta$ (pg/ml) & TNF- $\alpha$ (pg/ml) \\
\hline 1 & Control & $105.23 \pm 1.22$ & $133.71 \pm 5.37$ \\
\hline 2 & $\begin{array}{l}A \beta_{1-42} \\
(10 \mu M)\end{array}$ & $\begin{array}{l}889.87 \pm \\
17.89^{* * *}\end{array}$ & $977.84 \pm 36.52^{* * *}$ \\
\hline 3 & Met-L-JG & $511.69 \pm 9.54$ & $475.83 \pm 20.30^{\# \# \# ~}$ \\
\hline \multicolumn{4}{|c|}{$\begin{array}{l}\text { Statistical significance was determined by one way ANOVA followed by } \\
\text { Tukey's multiple comparison tests using Graph pad prism Version } 6.0 \text {. } \\
\text { Values are represented as Mean } \pm \text { SEM, Superscript }{ }^{* * *} \text { denotes } p<0.001 \\
\text { vs control, \#\#\# denotes } p<0.001 \text {; vs } A \beta_{1-42} \text { groups respectively, (A } \beta \text { : } \\
\text { Amyloid beta). }\end{array}$} \\
\hline
\end{tabular}

\section{Morphology results}

The control SH-SY5Y cells are tiny, highly light retractile, fibroblast-like and good morphological features and growing densely. $A \beta_{1-42}(10 \mu \mathrm{M})$ intoxication caused morphological changes with condensed cell density, swollen, decreased proliferation and differentiation of cells in comparison to the control cells. Post-treatment with met-L-JG extracts have significantly protected the cells from the $A \beta_{1-42}$ toxicity which is evidenced by increased cell density and proliferation, in comparison to $A \beta_{1-42}(10 \mu \mathrm{M})$ treated cell lines. However, met-L-JG treatment has shown better morphological restoration against $A \beta 1-42$ in vitro model of Alzheimer's diseases.

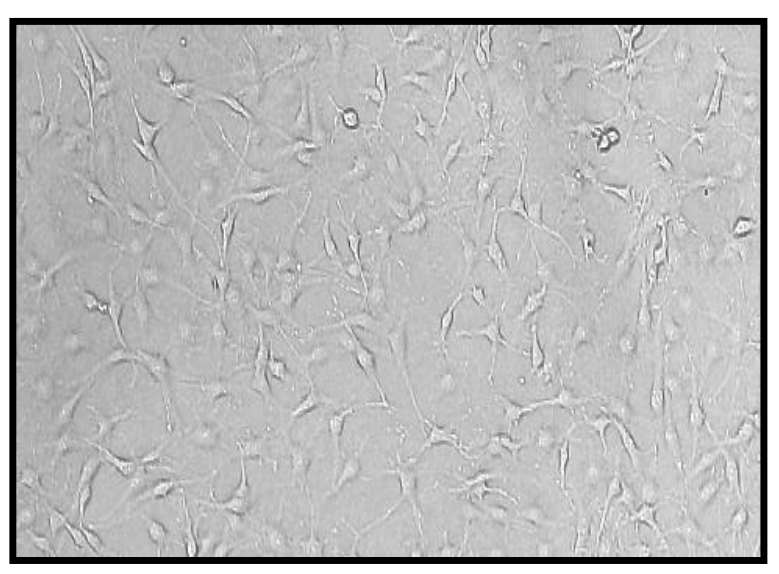

Control

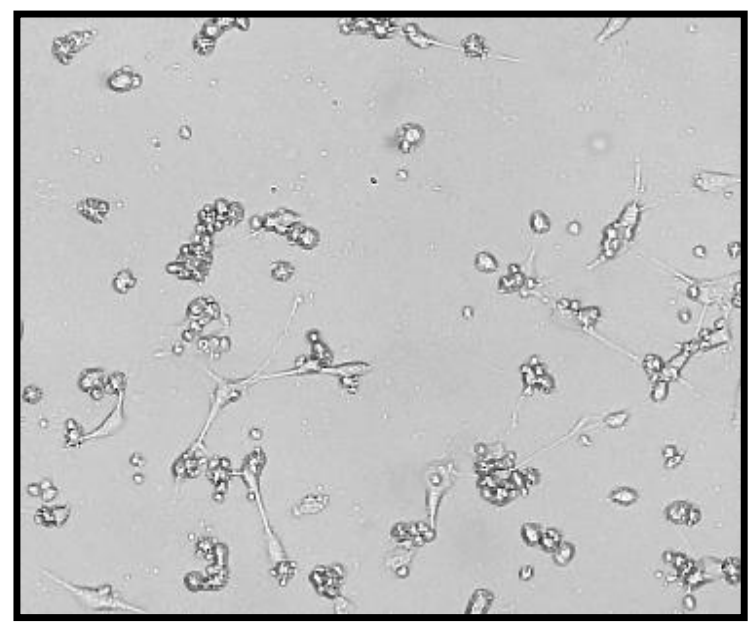

$A \beta_{1-42}$

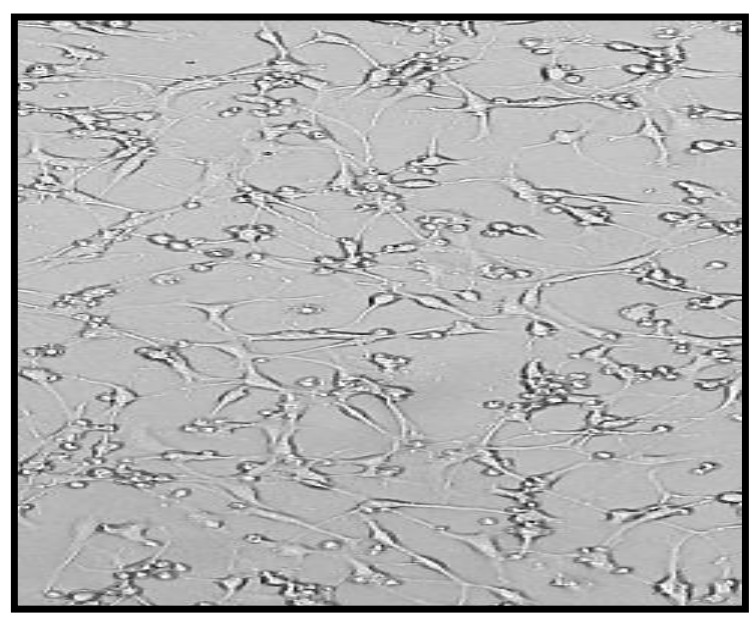

Met-L-JG

\section{DISCUSSION}

The preliminary phytochemical studies of methanolic extract of leaves of Jatropha gossypiifolia showed the presence of phenolic compounds \& flavonoids, Carbohydrates \& glycosides, Protein \& aminoacids, Alkaloids, Phytosterol, Saponins. These phytochemical contstituents identified were further subjected to GC-MS analysis. The GC-MS analysis has shown the presence of 1,1,5-Trimethyl-1,2-dihydronaphthalene, Methyl 10,12pentacosadiynoate, Dodecanoic acid, methyl ester, Methyl tetradecanoate, 3,7,11,15-Tetramethyl-2-hexadecen-1-ol, Cyclopropanepentanoic acid, 2-undecyl-, methyl ester, 
trans-, n-hexadecanoic acid, 9,12,15- Octadecatrienoic acid (Z,Z,Z)-, Heptadecanoic acid, 16-methyl-methyl ester-, 7,8Epoxylanostan-11-ol, 3-acetoxy, Cis, Cis, Cis- 7,10,13 Hexadecatrienal. From this some important compounds of Cis, Cis, Cis 7,10,13 Hexadecatrienal, Heptadecanoic acid 16-methyl-methylester-, only subjected for molecular docking studies. The results have shown that donepezil had the highest binding score of -9.2 followed by Cis, Cis, Cis7,10,13 Hexadecatrienal (7.6), Heptadecanoic acid 16methyl-methylester (7.0). The docked donepezil and the compound molecules were almost found to occupy the same binding site and form similar interactions to those formed by donepezil in the crystal structure, thus confirming the similar activity of the compounds. Inhibition concentration $\left(\mathrm{IC}_{50}\right)$ of Jatropha gossypiifolia was found to be $55.35 \mu \mathrm{g} / \mathrm{ml}$ by MTT assay. The percentage of viability of cells was found to be 77.96 in treatment with met-L-JG. Effect of methanolic extract of leaves of Jatropha gossypiifolia (met-L-JG). in Aß1-42 intoxicated SH-SY5Y cell lines was found to be LPO level 53.62, NO level (88.81), GSH level (71.28), SOD (17.58), CAT (0.723), IL- $1 \beta$ (511.69), TNF$\alpha$ (475.83). The in vitro results showed that the met-L-JG had the potent activity against alzheimer's.

\section{CONCLUSION}

The protein and ligand plays an important role in structural based drug design. In this study phytochemicals obtained from the leaves of Jatropha gossypiifolia by Gas Chromatography Mass spectrometry (GC-MS) analysis showed the presence of different bioactive compounds provides effective use of plant parts for various ailments by traditional specialists. In this work AChE docked against the phytochemical constituents of Jatropha gossypiifolia leaves such as Cis, Cis, Cis - 7,10,13 Hexadecatrienal, Heptadecanoic acid16-methyl-methyl ester-, were found to be promising lead targets against alzheimer's based on molecular docking analysis and in vitro study. So, in vivo approaches are therefore recommended to elucidate the molecular mechanism of these compounds to act as potent drugs against alzheimer's.

\section{Acknowledgement:}

I wish to express my sincere gratitude to Department of Pharmacology, Vinayaka Mission's College of Pharmacy, Salem, Tamilnadu, India for providing necessary facilities to carry out this research work.

\section{REFERENCES}

1. Mecocci P, Boccardi V, Cecchetti R, Bastiani $P$, Scamosci $M$, Ruggiero $C$ and Baroni $M$ : A long journey into aging, brain aging, and alzheimer's disease following the oxidative stress tracks. Journal of Alzheimer's Disease 2018; 62(3): 1319-1335.

2. Ferreira-Vieira HT, Guimaraes MI, Silva RF and Ribeiro MF: Alzheimer's disease: targeting the cholinergic system. Current Neuropharmacology 2016; 14(1): 101-115.
3. Pope $\mathrm{CN}$ and Brimijoin S: Cholinesterases and the fine line between poison and remedy. Biochemical Pharmacology 2018; 19: 433-446.

4. Blokland A: Acetylcholine: A neurotransmitter for learning and memory? Brain Research Reviews 1995; 21(3): 285-300.

5. Francis PT, Palmer AM, Snape M and Wilcock GK: The cholinergic hypothesis of Alzheimer's disease: a review of progress. Journal of Neurology, Neurosurgery \& Psychiatry 1999; 66(2): 137-147.

6. Arendt $\mathrm{T}$, Bruckner $\mathrm{MK}$, Morawski $\mathrm{M}$, Jager $\mathrm{C}$ and Gertz HJ: Early neuron loss in Alzheimer's disease: cortical or subcortical? ActaNeuropathological Communications 2015; 3(1): 10.

7. Carter J and Lippa CF: $\beta$-Amyloid, neuronal death and Alzheimer's disease. Current Molecular Medicine 2001; 1(6): 733-737.

8. Geula $C$ ndMesulam $M$ : Cholinesterases and the pathology of Alzheimer disease. Alzheimer disease and associated disorders 1995; 9(2): 23-28.

9. Lombardo $S$ amdMaskos $U$ : Role of the nicotinic acetylcholine receptor in Alzheimer's disease pathology and treatment. Neuropharmacology 2015; 96: 255-262.

10. Paul S, Jeon WK, Bizon JL and Han JS: Interaction of basal forebrain cholinergic neurons with the glucocorticoid system in stress regulation and cognitive impairment. Frontiers in Aging Neuroscience 2015; 7(43): 1-11.

11. Kokate, C.K., "Practical Pharmacognosy" 2002, p: 107114, 123-125,130. 2002: $1^{\text {st }}$ edition; 405-406, 426489.

12. Kokate, C.K., Evaluation of crude drug, Practical Pharmacognosy, 1985; $1^{\text {st }}$ edition; 122-135.

13. Kokate, C.K., Purohit A.P., Gokhale S.B., Fluorescence analysis and qualitative Phytochemical analysis, Practical Pharmacognosy, 2000: $4^{\text {th }}$ edition; 107-111.

14. Khandelwal K.R., "Practical Pharmacognosy" 1996, P: 15-148, 149-153,157-159,162-166.

15. Hossain M., Al-Hdhrami S., Weli A., Al-Riyami Q., AlSabahi J. Isolation, fractionation and identification of chemical constituents from the leaves crude extracts of Menthapiperta L grown in Sultanate of Oman. Asian Pacific J. Trop. Biomed., 2014;4(1):368-372.

16. Lu S., Wu J., Liu H., Zhao J., Liu K., Chuang C., Lin H., Tsai W., Ho y., The discovery of potential acetylcholinesterase inhibitors; A combination of pharmacophore modelling, virtual screening and molecular docking studies, Journal of Biomed Sci., 2012;(1)6:1-13.

17. Kaja S, Duncan RS, Longoria S, Hilgenberg JD, Payne AJ, Desai NM, Parikh RA, Burroughs SL, Gregg EV, 
Goad DL, Koulen P. Novel mechanism of increased $\mathrm{Ca} 2+$ release following oxidative stress in neuronal cells involves type 2 inositol-1,4,5-trisphosphate receptors. Neuroscience 2011;175:281-291.

18. Ohkawa $\mathrm{H}$, Ohishi N, Yagi K. Assay for lipid peroxides in animal tissues by thiobarbituric acid reaction. Anal Biochem 1979;95(2):351-358.

19. Green LC, Wagner DA, Glogowski J, Skipper PL, Wishnok JS, Tannenbaum SR. Analysis of nitrate, nitrite, and $[15 N]$ nitrate in biological fluids. Anal Biochem 1982;126(1):131-138.

20. Kakkar, P., Das, B., Viswanathan, P.N., A modified spectrophotometric assay of superoxide dismutase. Indian J BiochemBiophys. 1984;21(2): 130-132.

21. Beers, R.F. Jr., Sizer, I.W., 1952. A spectrophotometric method for measuring the breakdown of hydrogen peroxide by catalase. J Biol Chem. 1952;195(1):133140.

22. Jollow, D.J., Mitchell, J.R., Zampaglione, N., Gillette, J.R., 1974. Bromobenzene-induced liver necrosis. Protective role of glutathione and evidence for 3,4bromobenzene oxide as the hepatotoxic metabolite. Pharmacology. 1974;11(3):151-169.

23. Lowry, O.H., Rosebrough, N.J., Farr, A.L., Randall, R.J., Protein measurement with the Folin phenol reagent. J Bio Chem, 1951;193(1):265-275.

24. Roeske-Nielsen A, Fredman P, Mansson JE, Bendtzen $\mathrm{K}$, Buschard K. Beta-galactosylceramide increases and sulfatide decreases cytokine and chemokine production in whole blood cells. ImmunolLett. 2004;91(2-3):205-211.

Source of Support: None declared.

Conflict of Interest: None declared.

For any question relates to this article, please reach us at: editor@globalresearchonline.net New manuscripts for publication can be submitted at: submit@globalresearchonline.net and submit_ijpsrr@rediffmail.com 